\title{
Coherence in the Application of the Duty of Consistent Interpretation in EU Law
}

\author{
Sim Haket* \\ PhD Candidate Montaigne Centre for Judicial Administration and Conflict Resolu- \\ tion, Utrecht University
}

\section{Abstract}

The duty of consistent interpretation requires national courts to examine whether their laws can be interpreted consistently with EU law. This article examines whether this question is approached coherently by the United Kingdom Supreme Court (UKSC), and its predecessor, the House of Lords (UKHL); and the Dutch Supreme Court (HR) and Administrative Jurisdiction Division of the Council of State (Administrative Jurisdiction Division) and provides a sketch of the case law. ${ }^{1}$ The hypothesis of the article is that, on account of its design, the duty of consistent interpretation can be applied coherently at the same time as respecting the pluralistic legal orders of the Member States.

\section{Introduction}

Let me start out by mentioning a concept which is not the subject of this article. It is a well-known concept, which has occupied the minds of many EU scholars. This concept is pluralism, and it provides the background to this article's discussion on the relationship between consistent interpretation and coherence. ${ }^{2}$ The legal orders of the Member States - in which the duty of consistent interpretation is applied - refer to '(...) different legal, social and political contexts of application that may impact the meaning that EU rules end

* DOI 10.7590/187479815X14465419060541

Sim Haket is a PhD Candidate working on the project 'Consistent Interpretation of Directives: An EU Concept in a Pluralistic Legal Order'.

1 The HR has jurisdiction in civil, tax and criminal law cases, whereas the Administrative Jurisdiction Division has jurisdiction in administrative law cases.

2 Shortly put, pluralism can be understood as referring to a multiplicity of legal sites, jurisdictional orders and legal sources, M. Poiares Maduro, 'In Search of a Meaning and Not in Search of the Meaning: Judicial Review and the Constitution in Times of Pluralism' [2013] Wisconsin Law Review 544 . 
up having in each of those legal orders'. ${ }^{3}$ Although a pluralistic legal order has its virtues, it also produces a special need to seek coherence in the application of common rules. ${ }^{4}$ In this regard, it has been observed that ' $[\mathrm{t}]$ he European order seems to require an appeal to coherence [on account of the structure of the system; SWH] at the same time as it makes this appeal problematic'. ${ }^{5}$ The pluralistic nature of the EU legal order is clearly visible in the design of the duty of consistent interpretation. This means that consistent interpretation is par excellence an instrument suited to realise some of the strengths inherent to pluralism, but its application by courts from different Member States is also prone to the risk of an incoherent application. As such, the capacity of consistent interpretation to be responsive to the various domestic approaches to interpretation needs to be balanced with the requirement to seek coherence in the application of the law. This balance is all the more important as consistent interpretation - rather than direct effect - is probably the main instrument through which the effective application of EU law is enforced in the legal orders of the Member States. ${ }^{6}$

Having set out the background to this article, let me outline how the rest of the article proceeds. Section 2 introduces the duty of consistent interpretation. Section 3 outlines the concept of coherence to the extent necessary for this article. In order to test how coherently the duty of consistent interpretation is applied, section 4, the main part of this contribution, discusses a selection of judgments of the UKSC and UKHL, and the HR and Administrative Jurisdiction Division.

Ibid. 541, 546 .

cf. N. Krisch, 'The Case for Pluralism in Postnational Law', 12/2009 LSE Law, Society and Economy Working Papers http://papers.ssrn.com/sol3/papers.cfm?abstract_id=1418707 accessed 8 October 2015, 19-28, 40; L. Moral Soriano, 'A Modest Notion of Coherence in Legal Reasoning. A Model for the European Court of Justice' [2003] Ratio Juris 298. A number of authors mention the imperative of coherence to contain the risks attached to pluralism, D. Leczykiewicz, 'Why Do the European Court of Justice Judges Need Legal Concepts?' [2008] European Law Journal 785; S. Bertea, 'Looking for Coherence within the European Community' [2005] European Law Journal $170 ;$ M. Poiares Maduro, 'Europe and the constitution: what if this is as good as it gets?', in: J.H.H. Weiler \& M. Wind (eds), European Constitutionalism beyond the State (Cambridge 2003), 74; M. Poiares Maduro, 'Contrapunctual Law: Europe's Constitutional Pluralism in Action', in: N. Walker (ed.), Sovereignty in Transition (Oxford 2003), 501.

5 Bertea, 'Looking for Coherence within the European Community' 2005, 155. At 170 Bertea notes that ' $[\mathrm{a}] \mathrm{s}$ different national orders and divergent legal traditions overlap within this system, the system itself becomes especially vulnerable to centrifugal forces pushing towards new forms of fragmentation that may break its unity'.

6 D. Chalmers, G. Davies \& G. Monti, European Union Law (Cambridge 2014), 316. In the Dominguez judgment, the ECJ requires national courts to first attempt a consistent interpretation of national law before applying the instrument of direct effect, Case C-282/10 Dominguez, ECLI:EU:C:2012:33, par. 23 . 


\section{An Introduction to the Duty of Consistent Interpretation and the Identification of a Potential Pitfall}

After explaining the main features of the duty of consistent interpretation, I elaborate on the design of this instrument and further explain why there is a need to seek coherence.

\subsection{The Duty of Consistent Interpretation and Limitations}

The European Court of Justice (ECJ) established the duty of consistent interpretation in the Von Colson and Kamann judgment. ${ }^{7}$ After the ECJ had established that the remedy of direct effect was not available to give domestic effect to the provision of the Equal Treatment Directive prescribing adequate sanctions, ${ }^{8}$ it introduced an alternative remedy through which the case might be resolved. The ECJ pointed out that there had been a lengthy discussion during the proceedings as to whether a more suitable compensation was available under German law (which did meet the requirements of the Equal Treatment Directive). The ECJ gave the referring court the following instruction, which it had to take into account when answering that question:

'(...) the Member States' obligation arising from a directive to achieve the result envisaged by the directive and their duty under [Article 4(3) Treaty on European Union (TEU)] to take all appropriate measures, whether general or particular, to ensure the fulfilment of that obligation, is binding on all the authorities of Member States including, for matters within their jurisdiction, the courts. It follows that, in applying the national law and in particular the provisions of a national law specifically introduced in order to implement Directive No $76 / 207$, national courts are required to interpret their national law in the light of the wording and the purpose of the directive in order to achieve the result referred to in the third paragraph of [Article 288 Treaty on the Functioning of the European Union (TFEU)].'9

In order to further elucidate the duty of consistent interpretation, four aspects should be highlighted. Firstly, the Marleasing judgment clarified that the scope of the duty of consistent interpretation applies to all domestic legislation, i.e. '(...) whether the provisions in question were adopted before or after the directive

7 Case 14/83 Von Colson and Kamann, ECLI:EU:C:1984:153.

8 Article 6 of Council Directive $76 / 207 /$ EEC of 9 February 1976 on the implementation of the principle of equal treatment for men and women as regards access to employment, vocational training and promotion, and working conditions [1976] OJ L39/40.

9 Von Colson and Kamann, par. 26. 
$\left(\right.$ (...). ${ }^{10}$ As far as the scope is concerned it should be mentioned that, although the duty of consistent interpretation is most commonly applied in the context of directives, the duty also applies in relation to the EU Treaties, general principles of EU law, regulations and even recommendations."

Secondly, the Von Colson and Kamann judgment makes clear that the duty of consistent interpretation is based on Article 4(3) TEU, stipulating the duty of sincere cooperation, and Article $288 \mathrm{TFEU}$, requiring the implementation of directives (obviously the latter is not relevant if it is applied outside the context of directives). In the Pfeiffer judgment the ECJ added that the duty of consistent interpretation is 'inherent in the system of the Treaty, since it permits the national court, for matters within its jurisdiction, to ensure the full effectiveness of Community law when it determines the dispute before it'. ${ }^{12}$ In the Dominguez judgment, the scope of this sentence was extended to cover 'European Union law' as a whole. ${ }^{13}$

Thirdly, I will discuss what is required from national courts when they apply the duty of consistent interpretation. The ECJ's Marleasing judgment reformulated the position adopted in the Von Colson and Kamann judgment by holding that national courts are under a duty to interpret national law 'as far as possible' in conformity with EU law. What is 'as far as possible' and who determines this? It is clear that the national court ultimately determines whether national law can be interpreted consistently. ${ }^{14}$ In this regard Prechal correctly observes that:

Case C-106/89 Marleasing, ECLI:EU:C:1990:395, par. 8.

Case C-165/91 Van Munster, ECLI:EU:C:1994:359; Joined Cases C-270 and C-271/97 Sievers, ECLI:EU:C:2000:76; Case C-262/97 Engelbrecht, ECLI:EU:C:2000:492 (EU Treaties); Case C-246/06 Navarro, ECLI:EU:C:2008:19 (general principles of EU law); Joined Cases C-383 to C-385/06 ESF, ECLI:EU:C:2008:165, in particular par. 59 (regulations); Case C-322/88 Grimaldi, ECLI:EU:C:1989:646 (recommendations). To my knowledge, the ECJ has not yet explicitly acknowledged a duty to interpret national law in conformity with the Charter of fundamental rights of the EU. The only examples of consistent interpretation are provided in cases where secondary EU law is interpreted in conformity with the Charter, see e.g. Case C-400/10 McB, ECLI:EU:C:2010:582, par. 49 et seq; Joined Cases C-92 and C-93/o9 Volker und Markus Schecke and Eifert, ECLI:EU:C:2010:662, par. 46. However, since Article 6(1) TEU stipulates that the Charter ' (...) shall have the same legal value as the Treaties', and the latter are within the scope of the duty of consistent interpretation, I do not see why there would not be a duty to interpret national law in conformity with the Charter.

Joined Cases C-397 to C-403/01 Pfeiffer, ECLI:EU:C:2004:584, par. 114.

Dominguez, par. 24.

cf. Case C-131/97 Carbonari, ECLI:EU:C:1999:98, par. 49. Along the same line, Opinion of AG Kokott in Case C-499/08 Andersen, ECLI:EU:C:2010:248, par. 84; Opinion of AG Mengozzi in Case C-42/11 Lopes Da Silva Jorge, ECLI:EU:C:2012:151, par. 61. See also M.H. Wissink, 'Interpretation of private law in conformity with EU directives', in: A.S. Hartkamp \& others (eds), The influence of EU law on national private law (Deventer 2014), 125. 
'[w] hen searching for an answer to the question whether consistent interpretation is possible or not, and thus when addressing the issue of the discretion of the national courts under national law, the crucial factor is the approach, or methods or rules of interpretation or construction prevailing within the Member State concerned. ${ }^{, 15}$

Be that as it may, the national courts' discretion to determine whether it is possible to adopt a consistent interpretation of national law is not unfettered. ${ }^{16}$ I would like to discuss two ECJ judgments which provide directions to national courts when they apply the duty of consistent interpretation. The Pfeiffer judgment provides two relevant directions. First, it indicates that national courts are under a duty to interpret national law in conformity with EU law in particular when the national law has an implementing objective. ${ }^{17}$ In these circumstances, the ECJ assumes that it is easier for a national court to reach a consistent interpretation and therefore has higher expectations of the national court. ${ }^{18}$ There is something to be said for this assumption since, on the one hand, the material provisions of the national legislation will more or less point in the same direction as the directive and, on the other hand, a consistent interpretation will in that case usually tie in with the well-established method that legislation is interpreted in accordance with the objectives underlying its adoption (i.e. legislative intention). The latter is reinforced by the ECJ which, in the preceding paragraph of the judgment, holds that the national court must presume that the Member State intended to fulfil entirely the obligations of the directive whenever it exercises the discretion afforded to it under Article 288 TFEU. ${ }^{19}$ I will return to this aspect in subsection 4.2.1. The directions provided in the Pfeiffer judgment build on the Wagner Miret judgment. ${ }^{20}$ In addition to this, the Pfeiffer judgment also stipulates that:

'(...) if the application of interpretative methods recognised by national law enables, in certain circumstances, a provision of domestic law to be construed

15 S. Prechal, Directives in EC Law (Oxford 2005), 194, with a further reference to U. Everling, 'Zur Auslegung des durch EG-Richtlinien angeglichenen Rechts' [1992] Zeitschrift für Unternehmens- und Gesellschaftsrecht 388.

16 This appears correct for the substantively determinative provisions are part of EU law, and the duty to interpret national law in conformity with EU law is based on the EU Treaties. Moreover, all instruments of EU law require an effective application in the Member States' legal orders.

17 Pfeiffer, par. 113 .

18 Wissink emphasises that there is only one duty of consistent interpretation which does not apply with more or less force in one or the other situation. Therefore, the Pfeiffer judgment merely demonstrates that the ECJ expects that national courts should be able to adopt a consistent interpretation more easily when they interpret implementing legislation, M.H. Wissink, Richtlijnconforme interpretatie van burgerlijk recht (Deventer 2001), 93.

19 Pfeiffer par. 112.

20 Case C-334/92 Wagner Miret, ECLI:EU:C:1993:945, par. 20-1. 
in such a way as to avoid conflict with another rule of domestic law or the scope of that provision to be restricted to that end by applying it only in so far as it is compatible with the rule concerned, the national court is bound to use those methods in order to achieve the result sought by the directive. ${ }^{21}$

There is broad support for the view that the excerpt implies; if national law recognises the interpretative technique, national courts are bound to apply it if this enables a consistent interpretation. ${ }^{22}$ In addition to the Pfeiffer judgment there is the Björnekulla judgment. There the ECJ stated that the duty of consistent interpretation applies ' (...) notwithstanding any contrary interpretation which may arise from the travaux préparatoires for the national rule. ${ }^{23}$ Klamert attaches far-reaching conclusions to this excerpt, arguing that the judgment implies that there is '(...) an obligation for national courts to disregard an interpretation based on legislative materials in favour of a consistent interpretation (...)'. ${ }^{24}$ However, Prechal has provided a more nuanced interpretation, in which the relevant passage of Björnekulla is understood as a confirmation of the fact that EU law '(...) may set limits to certain methods of interpretation'. ${ }^{25}$

Finally, the ECJ's case law mentions specific limitations that attach to the duty of consistent interpretation. There is in the first place the prohibition of an interpretation contra legem. ${ }^{26}$ Advocate General Jacobs has described an interpretation contra legem as an interpretation of national law 'which is contrary to the express terms of the relevant legislation'. ${ }^{27}$ In addition to this, the ECJ has also limited the duty of consistent interpretation where this would, of itself and independently of domestic implementing legislation, '(...) have the effect of determining or aggravating the liability in criminal law (....). ${ }^{28}$ This article

21 Pfeiffer, par. 116. This direction was repeated in Case C-12/08 Mono Car Styling,

ECLI:EU:C:2009:466, par. 63.

22 Wissink 2014, 145; R.J.G.M. Widdershoven, 'De doorwerking van richtlijnen in een samengestelde Europese rechtsorde', in: H.R.B.M. Kummeling \& others (eds), De samengestelde Besselink (Oisterwijk 2012), 214; K. Sawyer, "The Principle of "interpretation conformé": How Far Can or Should National Courts Go when Interpreting National Legislation Consistently with European Community Law?' [2007] Statute Law Review 177; M. Klamert, 'Judicial implementation of directives and anticipatory indirect effect: connecting the dots' [2006] CML Rev. 126o; Prechal, Directives in EC Law 2005, 199.

23 Case C-371/O2 Björnekulla, ECLI:EU:C:2004:275, par. 13.

24 Klamert 2006, 1258-9.

25 S. Prechal, 'Joined Cases C-397/01 to C-403/01, Bernhard Pfeiffer et al., judgment of the Court (Grand Chamber) of 5 October 2004, nyr' [2005] CML Rev. 1459.

26 Case C-105/03 Pupino, ECLI:EU:C:2005:386, par. 47. See Case C-212/04 Adeneler, ECLI:EU:C:2006:443, par. 110 for a reference to the prohibition of an interpretation contra legem in the context of a directive instead of a framework decision.

27 Opinion of AG Jacobs in Case C-456/98 Centrosteel, ECLI:EU:C:2000:137, par. 32.

28 Case 80/86 Kolpinghuis, ECLI:EU:C:1987:431, par. 13. In the Netherlands this limitation has been extended to cover administrative fines, which are considered to be a criminal charge, Administrative Jurisdiction Division 4 March 2009, ECLI:NL:RVS:2009:BH4621, AB 2009, 156, m.nt. R.J.G.M. Widdershoven (Mandemakers), par. 2.6.2. 
does not, however, look at domestic judgments in which criminal liability is determined.

\subsection{The Strength of the Duty of Consistent Interpretation:} A Pitfall in Terms of Coherence?

While the first two aspects of the duty of consistent interpretation are relatively clear-cut, this is not so much the case for the third aspect, and the prohibition of an interpretation contra legem. On account of this ambiguity national courts have a larger measure of discretion in those areas. However, if this were otherwise, much of the strength of the duty of consistent interpretation would be lost. This strength resonates well with pluralism and lies in the fact that consistent interpretation contributes to a more harmonious relationship between EU law and national law as, unlike direct effect, EU law is given effect within the framework of national law and interpretative methods. Clearly, if the ECJ were to prescribe whether national law can or cannot accommodate a consistent interpretation, this strength would be lost. Moreover, it would undermine the division of functions between the ECJ and national courts. ${ }^{29}$ It should therefore be accepted that certain aspects of the duty of consistent interpretation leave a significant measure of discretion to national courts. Importantly, this discretion exists in respect of probably the most decisive aspects for its application (i.e. 'as far as possible' and contra legem). It is presumed that the national courts' approach towards these two aspects is influenced heavily by features that form an essential part of their domestic legal culture, such as methods of construction and the position of the judiciary towards the legislature, ${ }^{30}$ features which differ between the Member States; the United Kingdom and the Netherlands are no exception in this regard. ${ }^{31}$ At first sight, it might seem that risks of incoherence are most likely to occur in respect of these discretionary aspects of the duty of consistent interpretation. However, in section 4 I will demonstrate that this is only partially true.

29 Prechal Directives in EC Law 2005, 194.

30 W. Mattli \& A.M. Slaughter, 'The Role of National Courts in the Process of European Integration: Accounting for Judicial Preferences and Constraints', in: A.M. Slaughter, A. Stone Sweet \& J.H.H. Weiler (eds), The European Court and National Courts - Doctrine and Jurisprudence (Oxford 1998), 272.

31 G. Betlem, 'Richtlijnconforme uitleg: interpretatieve doorwerking van EG-recht' [1994] Intellectuele Eigendom \& Reclamerecht 106. 


\section{Theories of Coherence and the Duty of Consistent Interpretation}

This section first looks at theories of coherence. At the end of this section, I will explain which theories are most useful for this article and set out the way in which the concept of coherence is applied in section 4 .

Why should we seek coherence in the first place? A number of arguments justify the proposition that coherence is a desirable feature of law. Coherence is considered to be conducive to legal certainty; it enhances the intelligibility of the legal system and the consistency of normative statements. ${ }^{32}$ These considerations acquire additional significance in an EU law context: several authors have referred to the need of a coherent application of EU law on account of the pluralistic nature of the EU legal order, making it particularly vulnerable to fragmentation..$^{33}$ Bertea observes that:

'(...) to appeal to coherence is to take seriously the pluralism of the admissible criteria of sound adjudication and the elements forming a legal system, both, and so to strive to impart an order to a plural entity, making this intelligible without denying its multiple nature. ${ }^{34}$

Also, on the basis of the work of Bengoetxea, MacCormick and Soriano, who establish a link between coherence and integration, it is possible to argue that coherence stimulates integration..$^{35}$ Although a detailed enunciation of this merit of coherence would require a descent into the recesses of legal philosophy - an exploration which is outside the scope of this article - it does not seem difficult to comprehend the merits of this argument. ${ }^{36}$ Just compare the situation where the parties to a Treaty either apply a common set of rules in a coherent manner or, conversely, adopt divergent practices, leading to a fragmented application of the said rules.

32 Moral Soriano 2003, 298, 302; Bertea, 'Looking for Coherence within the European Community' 2005,170 . In this regard it can also be said that coherence connects to the rule of law, N.

MacCormick \& R. Summers, 'Interpretation and Justification', in: N. MacCormick \& R. Summers (eds), Interpreting Statutes (Aldershot 1991), 535.

33 See the introduction to this article.

34 See S. Bertea, 'The Arguments from Coherence: Analysis and Evaluation' [2005] Oxford Journal of Legal Studies 373.

35 J. Bengoetxea, N. MacCormick \& L. Moral Soriano, 'Integration and Integrity in the Legal Reasoning of the European Court of Justice', in: G. de Búrca \& J.H.H. Weiler (eds), The European Court of Justice (Oxford 2001), 48.

36 Based on the Dworkinian notion of integrity, which is supported by coherence, while itself stimulating a process of integration, R. Dworkin, Law's Empire (Fontana 1986), 164-67, 176275 . 
However, mentioning some of the virtues of coherence in relation to the EU legal order cannot allay the need to elaborate the meaning of the concept of coherence itself. Unfortunately, there does not appear to be a broad consensus with regard to the meaning of coherence, even if we allow this to pertain to a specific context, such as EU law. ${ }^{37}$ Coherence has been described as a concept which is '(...) inherently elusive and slippery' ${ }^{38}$ Pethick attempts to explain the difficulties surrounding the concept. ${ }^{39}$ He argues that, on the one hand, some authors who are afraid to be more specific, merely provide an underdetermined and impracticable account of the concept. On the other hand, however, there are authors who deploy an ever-increasing complex, and over-specified approach to coherence. In Pethick's opinion the latter approach is often flawed as a result of the oversight that characteristics of the specific object to which coherence is applied are misidentified as characteristics of the concept of coherence itself. This is said to produce even greater terminological ambivalence which is clearly irreconcilable since the authors develop their particular conception in relation to different objects.

The briefly-worded references to coherence are usually summarised in just a few words, e.g. coherence as a concept alluding to 'cohesion', ${ }^{\circ}$ 'consonance', ${ }^{11}$ and a reference to 'making sense as a whole', ${ }^{42}$ 'hanging (or 'sticking' ${ }^{43}$ ) together', sometimes combined with a characterisation in the negative, e.g. coherence as requiring the absence of inconsistencies. ${ }^{44} \mathrm{I}$ believe they all reflect what the concept of coherence embodies. For the purpose of this article they are not therefore considered irrelevant. However, it would be even better of course if a more specific meaning of coherence were available.

What do more detailed accounts, which might be relevant for the purpose of section 4, look like? A useful contribution has been provided by Bertea, who wrote an article on coherence and the EU. First, he distinguishes between different 'types' of coherence. It may sometimes seem as if these 'types' of coherence give a twist to the concept of coherence itself, providing a more specified

37 S. Pethick, 'On the Entanglement of Coherence' [2014] Ratio Juris 117; Bertea, 'The Arguments from Coherence: Analysis and Evaluation' 2005, 371-2.

38 Bertea, 'The Arguments from Coherence: Analysis and Evaluation' 2005, 371.

39 See in particular Pethick 2014, 132.

40 G. Zaccaria, 'Hermeneutics and Narrative Comprehension', in: P. Nerhot (ed.), Law, Interpretation and Reality (Dordrecht 1990), 269.

41 V. Villa, 'Normative Coherence and Epistemological Presuppositions of Justification', in: Nerhot 1990,433 .

42 N. MacCormick, 'Coherence in Legal Justification', in: A. Peczenik (ed.), Theory of Legal Science (Reidel 1984), 235.

43 Pethick 2014, 128-31.

44 See Bertea, 'Looking for Coherence within the European Community' 2005, 156-7 with references to literature. 
account of coherence in the particular context to which the type refers. This point may be illustrated by giving an example. With regard to the coherence of the various components of a legal system, one of the attributes of coherence can, for example, be that it amounts to '(...) presenting the law as a meaningful whole, whose components are mutually supportive and interdependent rather than the mere result of the (not necessarily interconnected) claims of an authority'. ${ }^{45}$ At first sight, this sentence might appear to be much more elaborate than the description of coherence discussed in the previous paragraph. Yet, on further consideration, the only parts of the sentence that say something about the meaning of coherence as such are 'meaningful whole', 'mutually supportive' and 'interdependent'. This does not really differ that much from the brieflyworded references that we saw in the previous paragraph. It is only the object to which it is applied, i.e. components of legal systems, which make this account look more specific. The description helps us understand the features that components of a legal system are required to possess in order to cohere, but does not tell us much about the meaning of coherence as such. Most of the descriptions of 'types' of coherence share this characteristic. ${ }^{46}$ In my opinion, this first attempt to arrive at a more specific meaning is of little help for the purpose of this article. However, after having looked at the different types of coherence, Bertea identifies common traits. He mentions four traits, of which three are relevant. ${ }^{47}$ In the first place coherence is seen:

'as a form of supportive rationality (...) the elements of a coherent structure are mutually supportive and reinforcing (...) [t]he type of relationship coherence hints at is that of interdependence understood as a connection that is (...) circular and symmetrical.'

Second, a decision is coherent for it is in conformity with characteristics of pre-existing decisions; it is '(...) a conservative criterion of adjudication, a standard that places emphasis on the past and on the obligation to adhere to such law as was enacted beforehand'..$^{8}$ Although this is clearly related to pre-

45 Ibid. 157.

46 cf. e.g. the application of coherence with regard to legal reasoning, in which regard it is mentioned that it requires that arguments are 'well-connected'. Another example of an elaboration that does not really work can be found in the area of 'adjudicative coherence'. This provides that judges are required to follow the letter of the law only to the extent that the coherence of the system is not thereby jeopardised. Yet, what does coherence mean?

47 Bertea, 'Looking for Coherence within the European Community' 2005, 159-60. Bertea's fourth point is that there is no formal definition of coherence.

48 See also J. Raz, 'The Relevance of Coherence', in: J. Raz (ed.), Ethics in the Public Domain. Essays in the Morality of Law and Politics (Oxford 1994), 302. 
cedent ${ }^{49}$ it may be wondered in what respect coherence really adds something to that concept in the description of this trait. Third, coherence is conceived of as a concept which refers to a number of elements. Bertea notes that, while there is no agreement on the precise features composing coherence, it should at least include 'consistency, comprehensiveness and completeness (...), support (...) and cross-connection and mutual justification between the different parts of a whole..$^{50}$ These different elements cannot all be fulfilled at the same time to the same extent. ${ }^{51}$ It seems though that this third trait is not so much meant as an independent specification of coherence, but is rather a collection of the most important briefly-worded elements recognised in the literature on coherence.

In addition to this sketch of the main elements of the meaning of coherence provided by Bertea, the work of Bengoetxea, MacCormick and Soriano, provides useful information on what the concept of coherence requires when it is applied in a context of adjudication. They observe that it would seem that coherence is not about finding a single, universal principle, through which all decisions delivered within a given legal order are in some way reconcilable; this would disregard the varying value of arguments for individual cases and inappropriately fix a priority among them. ${ }^{52}$ Rather, a set of potentially colliding features or values will often require a degree of balancing, attuned to the specific circumstances of the case, so that in the end a solution is adopted that makes sense. ${ }^{53}$ Two remarks are necessary here. First, the idea of balancing potentially colliding features or values resonates well with pluralism. Second, the sentence seems to exclude the possibility of achieving coherence through a more universal principle. I agree that coherence should not be achieved by disregarding important differences between the Member States. However, on account of its flexible design, it is not sure whether one should immediately exclude that possibility in respect of the duty of consistent interpretation. In addition to the above statement, Bengoetxea, MacCormick and Soriano also indicate that coherence

49 cf. Gerbrandy who relates coherence to precedent and the doctrine of stare decisis, A. Gerbrandy, Convergentie in het mededingingsrecht (Boom Juridische Uitgevers 2009), 128 with further references.

50 With reference to R. Alexy \& A. Peczenik, 'The Concept of Coherence and Its Significance for Discursive Rationality' [1990] Ratio Juris 130-47; K. Kress, 'Coherence', in: D. Patterson (ed.), A Companion to Philosophy of Law and Legal Theory (Oxford 1999), 533-6.

$5^{1}$ Bertea, 'Looking for Coherence within the European Community' 2005, 159-60, with further reference to among others MacCormick 1984 who, on 238, comments that something is coherent where its different parts are instrumentally or intrinsically related to the realisation of common values.

52 cf. Moral Soriano 2003, 297-98; See also Bengoetxea, MacCormick \& Moral Soriano 2001, 64, where it is explained that such a rigid approach leads to unjustified differences, and therefore unfavorable, results from a coherence perspective.

53 Bengoetxea, MacCormick \& Moral Soriano 2001, 64. 
requires an active attitude from judges whereby they make - instead of deduce or discover - plausible connections between different elements of the legal system (i.e. both the national and EU component), where necessary reconstructing the legal system. ${ }^{54}$ This resembles the ECJ's expectations when national courts apply the duty of consistent interpretation. ${ }^{55}$

To conclude this section, I will explain what the above theories on coherence mean for the article's approach to the concept. As a starting point 'hanging or sticking together' as a description of coherence is used, which expresses a symmetrical relationship and mutual supportiveness. ${ }^{5}$ Beyond this, it is useful to look at the use of coherence in an adjudicative context. This refers to the importance of the ability to weigh conflicting elements, and the need for flexibility in relation to the specific circumstances of a case. On the basis of these observations, the aim of the next section is to determine whether national judgments applying the duty of consistent interpretation 'stick together' while maintaining a degree of flexibility and scope for balancing. It will be recalled that the hypothesis of this article is that the design of the duty of consistent interpretation, as developed by the case law of the ECJ, facilitates this balance.

\section{Application of the Duty of Consistent Interpretation in the United Kingdom and the Netherlands: A First Sketch}

In section 4, I will first look at the application of the more restrictive elements of the ECJ's case law and consider the relationship with coherence. In the second subsection, the same will be done for the application of elements that leave more discretion to the national courts. Both subsections do

54 Ibid., 66-7.

55 It has been submitted that national courts must make an utmost effort to obtain an interpretation of national law that is in conformity with EU law, cf. Wissink 2001, 106; J.M. Prinssen, Doorwerking van Europees recht: de verhouding tussen directe werking, conforme interpretatie en overheidsaansprakelijkheid (Deventer 2004), 51; Prechal, Directives in EC Law 2005, 209; J.H. Jans, S. Prechal \& R.J.G.M. Widdershoven, Europeanisation of Public Law (Europa Law Publishing 2015), 75. In doing so, national courts should actively push the boundaries of what is possible in their domestic legal orders, cf. Prinssen 2004 (supra); Wissink 2001 (supra); H. Gilliams, 'Horizontale werking van richtlijnen: dogma's en realiteit', in: H. Cousy \& others (eds), Liber amoricum Walter van Gerven (Deventer 2000), 228; G.C. Rodrigues Iglesias \& K. Riechenberg, 'Zur richtlinienkonforme Auslegung des nationalen Rechts (Ein Ersatz für die fehlende horizontale Wirkung?)', in: O. Due, M. Lutter \& J. Schwarze (eds), Festschrift für Ulrich Everling (Baden-Baden 1995), 1224; W. van Gerven, 'The Horizontal Effect of Directive Provisions Revisited: The Reality of Catchwords', in: D. Curtin \& T. Heukels (eds), Institutional Dynamics of European Integration (Dordrecht 1994) 346.

56 In support of the proposition that coherence means 'sticking together', Pethick uses an etymological argument that 'co' refers to together and 'haerere' to stick, Pethick 2014, 130. 
not discuss the impact of the duty of consistent interpretation on coherence from the internal perspective of the Member State's legal order since it is, at least to some extent, self-evident that adjudication in an EU law context will often demand a divergent approach compared to wholly internal situations.

\subsection{Basic Principles of the Duty of Consistent Interpretation}

This subsection looks at the application of basic principles concerning the duty of consistent interpretation. It will be seen that assessing coherence in this area of the national case law is more straightforward in comparison to the case law discussed in subsection 4.2. The judgments concern the scope and applicability of the duty of consistent interpretation.

In the Duke judgment the UKHL examined whether the Sex Discrimination Act 1975 could be interpreted consistently with Article 5(1) of the Equal Treatment Directive (prescribing equal treatment with regard to working conditions). Lord Templeman, with whom the other Law Lords agreed, dismissed the appeal. There are two striking features in respect of the UKHL's approach to consistent interpretation. First, it was considered to be a relevant factor that the Sex Discrimination Act 1975 was not passed to give effect to the directive. ${ }^{57}$ This seems to be related to the English doctrine of sovereignty of Parliament: a duty of consistent interpretation cannot, in a case such as Duke, be based on a corresponding will of Parliament. ${ }^{5}$ What is remarkable is that the judgment presents this circumstance as an absolute barrier to a consistent interpretation. If we look at Dutch case law from the same period, there are no equally explicit examples that emphasise the decisive role of parliamentary intention. In one judgment, the Administrative Jurisdiction Division examined the possibility of an interpretation of Article 53 of the Dutch Hunting Law in conformity with the Directive on the Conservation of Wild Birds. ${ }^{59}$ The text of the national provision was materially identical to its predecessor in the 1955 version of the Dutch law and when the judgment was delivered, Article 53 was not designated or

57 Duke v. Reliance Systems Ltd [1988] AC 618 (Lord Templeman), 638-9, 641.

58 Sovereignty of Parliament means that "no Act of the sovereign legislature (...) could be invalid in the eyes of the courts; that it is always open to the legislature, so constituted, to repeal any previous legislation whatever; that therefore no Parliament could bind its successors' and that '(...) in case of conflict between two Acts of Parliament, the later repeals the earlier', H.W.R. Wade, 'The Basis of Legal Sovereignty' [1955] Cambridge Law Journal 174. According to Craig '(...) the crucial factor was in part that the relevant national statutes had not been passed to give effect to [EU law] norms', P.P. Craig, 'Indirect Effect of Directives in the Application of National Legislation', in: M. Andenas and F. Jacobs (eds), European Community Law in the English Courts (Oxford 1998), 47. See also Wissink 2001, 39.

59 Council Directive 79/409/EEC of 2 April 1979 on the conservation of wild birds [1979]

OJ L1O3/1. 
amended to serve an implementing objective. ${ }^{60}$ Yet, this did not prevent the court from adopting a consistent interpretation. ${ }^{61}$ The judgment shows that the duty of consistent interpretation was not considered to be exclusively applicable in relation to implementing legislation. The second point with regard to the Duke judgment concerns the relationship between the duty of consistent interpretation and direct effect. On two occasions the UKHL states that the duty of consistent interpretation does not constrain the court to 'distort' the meaning of a domestic statute to enforce a directive which is not directly applicable in a dispute between individuals - in this regard it is necessary to recall that, since the ECJ's Marshall I judgment, ${ }^{62}$ it is well-established that directives cannot produce direct effect in these so-called 'horizontal relationships'. ${ }^{6}$ Surely, if the Von Colson and Kamann judgment established one thing, it is that the duty of consistent interpretation is not dependent on an EU law provision having direct effect. ${ }^{64}$ Although it does not seem to have been a persistent issue in the United Kingdom either, ${ }^{65}$ the HR never encountered any difficulties because the duty of consistent interpretation was applied to provisions lacking (horizontal) direct effect, also in its earlier judgments. In the Beets-Proper/Van Lanschot Bankiers judgment, which also concerned the enforcement of Article 5(1) of the Equal Treatment Directive, the HR interpreted Article 1637 ij of the former Dutch Civil Code in conformity with that provision. ${ }^{66}$

I will now look at case law that shows the importance of determining the legal basis for the duty of consistent interpretation, and the consequences for its applicability. Subsection 2.1 showed that the ECJ sees Articles 4(3) and 288 TFEU as the legal basis for the duty of consistent interpretation. Moreover, it has stated that the duty is inherent in the system of the Treaties. In the Netherlands this has never caused any issues. Dutch courts recognise that the obligation to adopt a conforming interpretation derives directly from EU law. The duty is not dependent on a domestic provision permitting the consistent interpretation

6o See also Kamerstukken II 1951/52, 2607 , no. 2, 5 .

61 Administrative Jurisdiction Division 6 March 1986, ECLI:NL:RVS:1986:BP8194, M \& R 1987, 6, m.nt. J.H. Jans.

62 Case 152/84 Marshall I, ECLI:EU:C:1986:84, par. 48.

63 Duke (Lord Templeman), 640-1.

64 For criticism on this part of the Duke judgment see J. Steiner, 'Coming to terms with EEC Directives' [1990] Law Quarterly Review 153; N. Foster, 'The Effect of the European Communities Act 1972, s. 2(4)' [1988] MLR 778-9.

${ }_{5}$ In the Litster judgment, which the UKHL delivered shortly after the Duke judgment, it adopted a consistent interpretation in a dispute between individuals, Litster and Others $v$. Forth Dry Dock Q Engineering Co. Ltd. and Another [1990] 1 AC 546.

66 HR 21 November 1986, ECLI:NL:HR:1986:AG5465, NJ 1987, 351, m.nt. P.A. Stein (BeetsProper/Van Lanschot Bankiers). For other examples see HR 13 February 1987, ECLI:NL:HR:1987:AC2901, NJ 1987, 503 (Spijkers/Benedik II); HR 13 September 1991, ECLI:NL:HR:1991:ZCo328, NJ 1992, 225, m.nt. P.A. Stein (Dekker/VJV). 
of national law. For example, in the HR's Wandelvierdaagse judgment, which will be discussed in more detail in subsection 4.2, reference is made to Article 288 TFEU when discussing the duty of consistent interpretation. In its ESF judgment, the Administrative Jurisdiction Division refers to Article 288 TFEU in conjunction with Article 4(3) TEU. ${ }^{67}$ However, matters are slightly more complicated in the United Kingdom where '(...) the source of EU law (...) is the European Communities Act 1972' ${ }^{68}$ Section 2(4) of the Act is the domestic provision permitting courts to apply the duty of consistent interpretation. ${ }^{69}$ The UKSC's Assange judgment, concerning the interpretation of the Framework Decision on the European Arrest Warrant, ${ }^{70}$ adopted under the former Title VI of the Treaty on European Union (Amsterdam Treaty), demonstrates the kind of difficulties to which this approach gives rise to. The Law Lords all agreed that the scope of the European Communities Act 1972 did not extend to the law adopted under the former Title VI. ${ }^{71}$ The UKSC's judgment is clearly in violation with EU law. In the Pupino judgment the ECJ held that the duty of consistent interpretation also applied to framework decisions. The peculiar result produced by the scope of the European Communities Act 1972 is caused by the way in which the United Kingdom implemented the Maastricht Treaty. Rawlings explains that the United Kingdom only amended the European Communities Act 1972 in respect of Community obligations:

'(...) thus on the basis that no Community rights and obligations are created, there is no provision for the inter-governmental pillars of the Union, the Titles on foreign and security policy and on justice and home affairs. ${ }^{72}$

This approach was continued when the Amsterdam Treaty was implemented. ${ }^{73}$ As a final remark, it should be pointed out that the Assange judgment is

67 HR 10 August 2007, ECLI:NL:HR:2007:AZ3758, AB 2007, 291, m.nt. R.J.G.M. Widdershoven (Wandelvierdaagse), par. 3.4; Administrative Jurisdiction Division 30 August 2006,

ECLI:NL:RVS:2006:AY7175, AB 2007, 240 (ESF), par. 2.12.3. See also Zijlmans in her case note for Administrative Jurisdiction Division 28 February 2007, ECLI:NL:RVS:2007:AZ9494, Jurisprudentie Milieurecht 2007, 65 (Fortis).

68 R. Gordon and R. Moffatt, EU Law in Judicial Review (Oxford 2014), 36.

69 This was already established in the Duke judgment (Lord Templeman), 639-40.

70 Framework Decision 2002/584/JHA of 13 June 2002 on the European arrest warrant and the surrender procedures between Member States [2002] OJ L190/1.

71 Assange v. Swedish Prosecution Authority [2012] UKSC 22 [2012] 2 AC 471 (Lord Mance), par. 209-10. The conclusion of the Assange judgment was repeated in Ministry of Justice, Republic of Lithuania v. Bucnys [2013] UKSC 71 [2014] AC 480, par. 20.

72 R. Rawlings, 'Legal politics: the United Kingdom and ratification of the Treaty on European Union: Part 1' [1994] Public Law 260.

73 As a side-note, it is interesting to point out that the United Kingdom has opted-out of all the pre-existing third pillar measures, and then immediately opted back in to a number of measures in EU police and criminal law (including the European Arrest Warrant). Measures that were adopted under the old third pillar have, since 1 December 2014, all the regular characteristics of EU law and are no longer subject to a transition regime (see Art. 10 of Protocol No. 36 to the Lisbon Treaty). See also S. Peers, 'The UK opts back into the European Arrest Warrant - 
a departure from the previous Dabas and Caldarelli judgments, which were also concerned with the Framework Decision on the European Arrest Warrant. ${ }^{74}$ These two judgments are discussed in subsection 4.2 and it is important to realise that, at the relevant time, it was still believed that the duty of consistent interpretation was applicable to law adopted under the former Title VI.

The question is of course what these judgments tell us about the coherence of the application of the duty of consistent interpretation. Firstly, the above discussion revealed two flagrant misapplications of the duty of consistent interpretation in the United Kingdom: the reference to the condition of direct effect in Duke, and the inapplicability of the duty of consistent interpretation to framework decisions in Assange. Equally obvious misapplications in Dutch case law were not encountered. In these cases we are dealing with a misapplication of basic rules which intend to achieve a minimum degree of integration of the way in which national courts apply consistent interpretation, and which aim to keep these approaches together. Once the misapplication has been established it will usually not be difficult to establish an incoherence with the application in another Member State (assuming the latter does not violate the same basic rule as well). Therefore, in case of such a flagrant misapplication, there will usually be a prima facie incoherence. The concept of coherence is almost superfluous; it is inferential, and is established by the preceding conclusion of the existence of a misapplication from the EU vis-à-vis Member State perspective. Secondly, since the issue had not yet been authoritatively decided, such a prima facie case of incoherence did not exist with regard to the question of whether the duty of consistent interpretation requires the establishment of an implementing objective (i.e. only applies to implementing legislation). Although the Marleasing judgment clearly established that the duty of consistent interpretation is also applicable to pre-existing provisions of national law, this was not a matter of course when the preceding Duke judgment had to be decided..$^{75}$ In other words, there was no clear violation from the EU vis-à-vis Member State perspective. Nonetheless, it may be argued that an incoherence occurs where the duty of consistent interpretation would be limited to this category of cases in the United Kingdom, whereas this limitation does not occur in the Netherlands. However, the source for such an incoherence would then be the Von Colson and Kamann judgment, which could have been clearer on this point. If the ECJ

and other EU criminal law' (EU law analysis, 1 December 2014) http://eulawanalysis. blogspot.nl/2014/12/the-uk-opts-back-in-to-european-arrest.htm accessed 8 October 2015.

74 Dabas v. Spain [2007] UKHL 6 [2007] 2 AC 31; Caldarelli v. Italy [2008] UKHL 51 [2008] 1 WLR 1724.

75 cf. Opinion of AG Slynn in Marshall I. But see, however, A. Arnull, 'The Duke case: an unreliable precedent' [1988] Public Law 316-7. 
does not provide clear directions on a basic principle of the duty of consistent interpretation, it creates the risk of an incoherent application.

\subsection{Discretionary Elements of the Duty of Consistent Interpretation}

As this article is only a preliminary sketch of the way in which national judgments apply the duty of consistent interpretation, it does not provide comprehensive coverage. Nonetheless, the selection of judgments reveals general trends in the case law that steer the application of the more discretionary aspects of the duty of consistent interpretation, and that provide a basis for examining their coherence. An analysis of the coherence of this category of judgments is particularly interesting, since the directions of the ECJ intentionally allow for differentiation. I first look at the argument that it is presumed that the legislature intends to comply with EU law, which occupies an important role in the approach to consistent interpretation in both the United Kingdom and the Netherlands, then I look at potential counter-arguments, and finally conclusions are drawn on the coherence of the application of discretionary aspects.

\subsubsection{The Presumption of the Intention to Legislate in Compliance with EU Law: A Shared Argument}

This presumption is found in the ECJ's Wagner Miret and Pfeiffer judgments, which both emphasise that when legislation has been adopted to implement EU law obligations, that domestic legislation will usually point in the same direction as EU law, and it is presumed that it is easier for a national court to reach a consistent interpretation. Interestingly, both United Kingdom and Dutch case law delivered before the ECJ's judgments already contained similar statements.

Searching Parliament's intention is the lynch-pin for any interpretation of statutes by United Kingdom courts. ${ }^{76}$ The presumption that Parliament intended to legislate in compliance with EU law found acceptance in early judgments, such as Pickstone and Litster. ${ }^{77}$ The same approach can be seen in the Caldarelli judgment (again, I emphasise that the judgment was delivered before the Assange judgment). Lord Bingham provided that

76 A. Kavanagh, 'The Role of Parliamentary Intention in Adjudication under the Human Rights Act 1998' [2006] Oxford Journal of Legal Studies 179.

77 Pickstone and Others v. Freemans Plc [1989] AC 66 (Lord Keith), 112; (Lord Oliver), 127; Litster (Lord Keith), 554 . 
'(...) the interpretation of Part 1 of the 2003 Act [i.e. the legislation implementing the Framework Decision on the European Arrest Warrant; SWH] must be approached on the assumption that Parliament did not intend the provisions of Part 1 to be inconsistent with the Framework Decision (...). ${ }^{78}$

In addition to these judgments, a presumption that the legislature intended to legislate in conformity with EU law is also found in section 2(4) of the European Communities Act 1972, the domestic legal basis for the duty of consistent interpretation. In the words of Laws:

' $[t]$ he effect is that section 2(4) of the European Communities Act falls to be treated as establishing a rule of construction for later statutes, so that any statute has to be read (whatever its words) as compatible with rights accorded by European law. ${ }^{79}$

In a judgment delivered by the HR on 2 May 1984 it held that it must be presumed that the legislature did not intend the Law on VAT to deviate from the definition of 'taxable person' provided in the Second and Sixth VAT Directive. ${ }^{80}$ The same approach was adopted in the HR's Buyck/Van den Ameele judgment. When the legislature adopted measures to implement Directive $77 / 189$ on the safeguarding of employees' rights in the event of a transfer of undertaking, ${ }^{8}$ it was overlooked that Dutch law would not protect the employee against dismissal if the nullity of the dismissal was not invoked on time. Referring to the ECJ's Bork judgment, the HR held that this was contrary to EU law. ${ }^{82}$ Since the Dutch legislation was intended to implement the directive, the nullity of the dismissal would also take effect without invocation by the employee. ${ }^{83}$ The same basic principle is applied in the HR's more recent Albron judgment, with reference to the ECJ's Pfeiffer judgment. ${ }^{84}$ The Administrative Jurisdiction Division seems to take a similar approach, although examples were mostly found where Dutch implementing legislation uses the same terminology as the EU law directives, so that it is only logical that the national court chooses an

78 Dabas par. 43. See also Office of the King's Prosecutor, Brussels v. Cando Armas and another [2005] UKHL 67 [2006] 2 AC 1 (Lord Bingham), par. 8.

79 J. Laws, 'Law and Democracy' [1995] Public Law 89. See also G. de Búrca, 'Giving Effect to European Community Directives' [1992] MLR 219.

80 HR 2 May 1984, ECLI:NL:HR:1984:AW8625, Beslissingen in Belastingzaken 1984, 295.

81 Council Directive 77/187/EEC of 14 February 1977 on the approximation of the laws of the Member States relating to the safeguarding of employees' rights in the event of transfers of undertakings, businesses or parts of businesses [1977] OJ L61/26.

82 Case 101/87 Bork ECLI:EU:C:1988:308, par. 18.

83 HR 29 December 1995, ECLI:NL:HR:1995:ZC1943, NJ 1996, 418 (m.nt. P.A. Stein), par. 3.4.

84 HR 5 April 2013, ECLI:NL:HR:2013:BZ1780, JAR 2013/125, m.nt. R.M. Beltzer (Albron Catering $B V / F N V$ Bondgenoten en John Roest), par. 3.4.3. 
interpretation that runs parallel with the ECJ's interpretation of the equivalent EU law definition. ${ }^{85}$ Dutch courts will usually attach weight to parliamentary history. ${ }^{86}$ The presumption that the legislature intended to fulfil EU law obligations will therefore often coincide with a well-established domestic interpretative technique.

It should be observed that all of the above judgments are examples where the courts interpreted legislation with a clear implementing objective. An important question in relation to this subsection is whether national courts would adopt a similar approach in respect of legislation which does not have this objective. As far as United Kingdom courts are concerned, Arnull has interpreted the Webb judgment in this way - a judgment which also concerned the Sex Discrimination Act 1975. He points out that:

'(...) the decision in Webb must be taken to establish that the purposive approach reflected in Pickstone and Litster [the EU law friendly approach; SWH] applies to all domestic provisions which overlap with [EU law], regardless of whether they were specifically designed to give effect to [EU law]. ${ }^{87}$

Indeed, the Webb judgment did not concern implementing legislation and the consistent interpretation required a substantial degree of distortion of the domestic statute. Also, it should be pointed out that the wording of section 2(4) of the European Communities Act 1972 supports this conclusion, for the duty of consistent interpretation covers '(...) any enactment passed or to be passed'. The provision does not therefore distinguish between implementing or other legislation. Yet, it has to be admitted that the judgments of the UKHL or UKSC that were part of my analysis, and which were delivered in the post-Webb era, do not provide a statement on this point that is equally clear as Arnull's. With regard to the Dutch courts, it should be mentioned that, on a number of occasions, they have successfully applied the duty of consistent interpretation to non-implementing legislation. See for example the judgment of the Administrative Jurisdiction Division in which it interpreted Article 26 of the Environmentally Dangerous Substances Act in such a way that it accommodated the precautionary principle and the duty to carry out the environmental risk assessment as prescribed by Directive $2001 / 18$ on the deliberate release into the envi-

85 Administrative Jurisdiction Division 2 November 2000, ECLI:NL:RVS:2000:AN6579, $A B$ 2001, 51, m.nt. H.F.M.W. van Rijswick; Administrative Jurisdiction Division 20 June 2001, ECLI:NL:RVS:2001:AB2437, AB 2001, 260, m.nt. Jongma/Tieman.

86 Wissink 2014, 150.

87 A. Arnull, 'The Law Lords and the European Union: swimming with the incoming tide' [2010] ELR 73 . 
ronment of genetically modified organisms. ${ }^{88}$ Another example is provided in the Administrative Jurisdiction Division's Fortis judgment. The court first concluded that Article 19d of the Nature Conservation Act - the rule that had been adopted with the specific purpose of implementing Article 6(3) of the Habitats Directive - could not be given a consistent interpretation (this part of the judgment will be discussed in more detail in subsection 4.2.2). Next, the Administrative Jurisdiction Division examined whether it was able to give a consistent interpretation to Article 16 of the Nature Conservation Act, a provision which did not have an implementing objective, and successfully did so. ${ }^{89}$ However, the judgments do not establish that the (powerful) presumption that the legislature intends to comply with EU law is extended to any legislation covered by EU law.

In summary, in the United Kingdom an implementing objective is considered a powerful argument in favour of a consistent interpretation and it has a solid basis in the United Kingdom legal system. The same can be said for the Netherlands, although the HR has been more explicit on the point than the Administrative Jurisdiction Division, and it has a different basis as well. At the same time, it has to be observed that both in the United Kingdom and the Netherlands, it is not really clear to what extent this presumption can be applied to legislation that does not have an implementing objective. Further analysis of case law applying the duty of consistent interpretation to non-implementing legislation is required to determine whether the outcome of the balancing of competing interpretations differs from cases that concern implementing legislation. In the remainder of this subsection I will look at other arguments that have a bearing on the application of the duty of consistent interpretation. First, arguments based on the wording of the rule that is being interpreted will be looked at. The other part deals with indications of 'conflicting' parliamentary intentions. This refers to the situation where a more specific intention of the legislature is available for one or more national rules, which is inconsistent

88 Administrative Jurisdiction Division 28 July 2004, ECLI:NL:RVS:2004:AQ5732, M R R 2004, 104 , m.nt. J.H. Jans, par. 2.3-2.4.2, giving effect to Directive 2001/18/EC of the European Parliament and of the Council of 12 March 2001 on the deliberate release into the environment of genetically modified organisms and repealing Council Directive 90/220/EEC [2001] OJ L106/1.

89 Fortis, par. 2.11. Other examples can be found in Administrative Jurisdiction Division 31 March 2000, ECLI:NL:RVS:2000:ZF4257, $A B$ 2000, 302, m.nt. Ch. Backes (Buitengebied Texel), par. 2.6.2.9.2; Administrative Jurisdiction Division 7 April 2004, ECLI:NL:RVS:2004:AO7095, $A B$ 2004, 460, m.nt. M.P. Jongma, par. 2.7.2. For the HR, see the Dekker judgment. cf. HR 17 January 2014, ECLI:NL:HR:2014:88, Intellectuele Eigendom Q Reclamerecht 2014, 41, m.nt. H.M.H. Speyart (Ryanair/PR Aviation) where the relevant legislation had no implementing objective, but the legislature believed that the existing provisions in the Dutch law on copyright were compatible with the provisions of Directive $96 / 9 / \mathrm{EC}$ of the European Parliament and of the Council of 11 March 1996 on the legal protection of databases [1996] OJ L77/20. 
with the general presumption that the legislation was intended to comply with EU law.

\subsubsection{Permissible Degree of Corrections on the Words Enacted by the Legislature}

A Different Approach in the United Kingdom and the Netherlands If an intention to comply with EU law obligations is established, United Kingdom courts will permit far-reaching corrections on the words used in the legislation when they apply the duty of consistent interpretation. In the UKHL's Cutter judgment, in which application of the duty of consistent interpretation was not decisive for the outcome of the case, Lord Clyde stated, in general terms, that in the context of EU law '(...) it is proper to strain to give effect to the design and purpose behind the legislation, and to give weight to the spirit rather than the letter'. ${ }^{\circ 0}$ The same point of view was expressed in more detail by Lord Mance in the Assange judgment. In his view the duty of consistent interpretation allows the courts to depart from '(...) a number of well-established rules of construction (...)', as well as '(...) the precise words used, e.g. by reading words in or out'.91 A presumption in favour of consistent interpretation is difficult to rebut. This would seem to be possible only if the legislation contains a clear and unequivocal intention to depart from EU law obligations (see further subsection 4.2.3). Furthermore, it is important to highlight that the presumption in favour of a consistent interpretation is not displaced by a contradictory enacted intention which refers to a petty feature of the legislation. This is also recognised by Lord Mance who adds to his previous statement that:

'[t]he main constraint is that the result must go "with the grain" or "be consistent with the underlying thrust" of the legislation being construed, that is, not be "inconsistent with some fundamental or cardinal feature of the legislation". ${ }^{92}$

Lord Mance's speech refers to the UKHL's Ghaidan judgment, which was decided under section 3 of the Human Rights Act 1998. This provision contains a corresponding interpretative duty with regard to the European Convention on Human Rights. It is very similar to section 2(4) of the European Communities Act 1972 and cases under the Human Rights Act 1998 are often considered as authoritative when applying the duty of consistent interpretation in an EU

$9 \circ$ Cutter v. Eagle Star Insurance co. Ltd. [1998] 1 WLR 1647 (Lord Clyde), ${ }_{16} 6$.

$9^{1}$ Assange (Lord Mance), par. 203.

$9^{2}$ Ibid. 
law context (and vice versa). ${ }^{93}$ In the Ghaidan judgment, Lord Rodger cogently describes what in his view is the correct approach to interpretation:

'(...) the key to what is possible for the courts to imply into legislation without crossing the border from interpretation to amendment does not lie in the number of words that have to be read in. The key lies in a careful consideration of the essential principles and scope of the legislation being interpreted' and '(...) in the [EU law] context, judges have rightly been concerned with the effect of any proposed implication, but have been relaxed about its exact form. ${ }^{94}$

A good example of the application of this approach is the Dabas judgment (again, it is emphasised that the judgment was delivered before the Assange judgment). Article 64(2) of the Extradition Act 2003 required the issuing of a certificate issued by 'an appropriate authority of the category 1 territory' (i.e. a United Kingdom authority was designated for this purpose), certifying that the conduct falls within the European framework list, and that the conduct is punishable under the law of the Member State of the requesting judicial authority with imprisonment or another form of detention of at least three years. This condition was not mentioned in the Framework Decision on the European Arrest Warrant, and the key question was whether the domestic legislation could be so interpreted as to mean that the requirement of a certificate was already fulfilled by the European Arrest Warrant itself. A normal construction of the national rule would entail that the certificate was included as an additional safeguard and, as Lord Scott observed, the requirement of a certificate '(...) was a clear requirement incorporated by Parliament (...)'. ${ }^{95}$ Nonetheless, the UKHL adopted a consistent interpretation. After having recalled the presumption that Parliament did not intend to legislate contrary to its EU law obligations, Lord Hope provided in his speech that he could:

'(...) find nothing in the wording of section 64(2), read as a whole and in the light of the other provisions of Part 1, to indicate that it was the intention of Parliament that a Part 1 warrant [i.e. a European Arrest Warrant] which clearly set out all the relevant information had to be accompanied by a separate document (....). ${ }^{96}$

This judgment, and the speeches of Lord Mance and Lord Rodger highlight the generous approach of the United Kingdom courts when they apply the duty [2006] EWCA Civ 29, par. 85.

94 Ghaidan v. Godin Mendoza [2004] UKHL 30 [2004] 2 AC 557 (Lord Rodger), par. 122.

95 Dabas (Lord Scott), paras 66, 70.

${ }_{96}$ Dabas (Lord Hope), par. 43. 
of consistent interpretation. It also confirms that the limits of the permissible degree of departure from the words enacted in the legislation derive essentially from constitutional boundaries and the proper task of the courts and their relationship vis-à-vis the legislature. ${ }^{97}$ Does it apply to both implementing and other legislation? There is little doubt that this approach applies to implementing legislation, but it is more difficult to determine whether the United Kingdom courts will use an equally generous approach when they interpret non-implementing legislation. On the one hand, it is interesting to see that the Ghaidan judgment is cited as a precedent: interpretation in conformity with the ECHR will often concern domestic legislation that was not adopted with the specific purpose of implementing the ECHR. In addition to this Edward and Lane refer to the above as the 'standard approach' by United Kingdom courts. ${ }^{98}$ On the other hand, there would seem to be more room for a conclusion that an interpretation is inconsistent with a 'cardinal' feature of the legislation in the absence of an overarching implementing objective. ${ }^{99}$

Although there are more judgments, I would like to start out by giving four examples to illustrate the point that the HR and Administrative Jurisdiction Division attribute more weight to grammatical considerations. First, in the HR's Van Asseldonk/Ter Schure judgment - a slightly older judgment - the issue was that the implementing legislation contained a generic exclusion for ecclesiastical offices, which was not stipulated in the Equal Treatment Directive. The court held that the Dutch implementing legislation could not accommodate a consistent interpretation on account of the unambiguous wording of the national rule. This interpretation was confirmed by the parliamentary history of the rule. ${ }^{100}$ Second, in the Pink Floyd judgment the HR was asked whether a rule stipulating that, when a copy is brought into circulation by, or with the consent of, the holder of the copyright, the latter has exhausted his exclusive right, could be interpreted as being limited to EU-wide exhaustion, as required by Directive 92/100, rather than worldwide exhaustion. ${ }^{101}$ The rule did not have an implementing objective. The HR rejected a consistent interpretation and the judgment shows that the unambiguous wording of the legal rule and legal certainty were

97 Ghaidan (Lord Nichollas), par. 33; (Lord Rodger), par. 122.

98 D. Edward \& R. Lane, Edward and Lane on European Union Law (Edward Elgar Publishing 2013), 354 .

99 In addition to these arguments, I refer to the discussion on the position of United Kingdom courts towards interpretation of implementing and other legislation in subsection 4.2.1.

100 HR 20 October 1995, ECLI:NL:HR:1995:ZC1846, NJ 1996, 330, m.nt. E.A. Alkema (Van Asseldonk/Ter Schure), par. 3.5.

101 Council Directive 92/100/EEC of 19 November 1992 on rental right and lending right and on certain rights related to copyright in the field of intellectual property [1992] OJ L346/61. 
the main reasons for this. ${ }^{102}$ The third judgment that will be discussed is the earlier mentioned Administrative Jurisdiction Division's Fortis judgment. According to Article 4(5) of the Habitats Directive, inclusion on the list of areas of Community interest established the applicability of, among others, Article 6(3) to those areas. However, Article 19d of the Nature Conservation Act, which was intended to provide the relevant legal framework for this category of areas, provided that it only applied once an additional appointment by the responsible Minister had taken place. Only in that case was there a competence to apply the protective provisions to the habitats. The Administrative Jurisdiction Division rejected a consistent interpretation on two main grounds and one additional argument. First, Article 19d clearly stipulated the requirement of an additional appointment by the responsible Minister. Second, an extensive interpretation of the scope of Article 19d - to also cover areas that are placed on the list but not yet appointed - would violate the principle of legal certainty. In addition to this, it points out that the prohibitory provisions of Article $19 \mathrm{~d}$ are the subject of administrative enforcement and qualify as an economic offense. ${ }^{103}$ Verschuuren and Jans, Widdershoven, and Zijlmans, all indicate that reasons related to legal certainty constituted the principal argument for rejecting the consistent interpretation. ${ }^{104}$ The first two case notes emphasise that this was due to the fact that this would entail the creation of a new competence. ${ }^{105}$ Finally, there is a second judgment from the Administrative Jurisdiction Division in which the clear words enacted by the legislature prevented a consistent interpretation. The grounds on which a permit could be refused and the relevant assessment framework were described unambiguously in the Ammonia and Livestock Farming (Interim Measures) Act, and it was explicitly stated that a permit could not be refused on other grounds. The Administrative Jurisdiction Division concluded that it was unable to read into this framework the requirement stipulated by the IPPC Directive to apply the 'best available techniques'. ${ }^{106}$

102 HR 25 October 1996, ECLI:NL:HR:1996:ZC2177, NJ 1997, 649, m.nt. D.W.F. Verkade (Pink Floyd/Rigu Sound), paras 3.3-3.4. See also Wissink 2001, 162. Parliamentary history was silent on the question whether the rule referred to $\mathrm{EU}$ or worldwide exhaustion. For further comments on this judgment I refer to C.R.A. Swaak, 'Consistent Interpretation of National Law: Dutch Courts on the Wrong Track?’ [1996] EPL 223; R. de Lange, 'Hoge Raad 25 oktober 1996 nr. 16.020' [1997] RAwb 36.

103 Fortis paras 2.10-2.11. See the case note of Widdershoven for this judgment, $A B$ 2007, 183, par. 5 .

104 Case note Verschuuren \& Jans, $M$ Q $R$ R 2007, 45, par. 2; Widdershoven, par. 4; Zijlmans, JM 2007,45 .

105 Ibid. Zijlmans does not address this issue.

106 Administrative Jurisdiction Division 13 November 2002, ECLI:NL:RVS:2002:AF0308, $M$ Q $R$ 2003, 39, m.nt. J.H. Jans, concerning Directive 2008/1/EC of the European Parliament and of the Council of 15 January 2008 concerning integrated pollution prevention and control [2008] OJ L24/8. For further examples in which a consistent interpretation of Dutch administrative law does not seem to be possible see J.H. Jans, 'European Law and the Inapplicability of the "Speciality Principle"' [2008/1] REALaw 40-1. 
Although these examples of Dutch case law indicate that the wording of a rule may sometimes prevent a consistent interpretation, it is necessary to mention the more recent HR's Albron judgment here. Consistent interpretation required that 'contract of employment' would have to be read as 'contract of employment or employment relationship'. The HR rejected the argument that, on account of the wording of the rule, this was not possible, and held that this is not always decisive. ${ }^{107}$ The HR points to the circumstance that the legislation was adopted for the purpose of implementing a directive which conferred rights upon individuals. While further case law is needed in order to determine the extent to which the Albron judgment represents a rule of generality, it confirmed a previous judgment, delivered outside the context of EU law. ${ }^{108}$

\section{The Prohibition of an Interpretation Contra Legem}

This limitation is predominantly linked to the wording of the rule of national law, and is therefore closely connected to the above discussion. ${ }^{109}$ Verschuuren and Jans contended that a consistent interpretation in the Fortis judgment would imply an interpretation contra legem. ${ }^{110}$ The limitation was also implicitly present in Pink Floyd. ${ }^{111}$ Other judgments from Dutch courts also refer to the concept without explicitly mentioning it. ${ }^{112}$ In due course Dutch courts started to refer directly to the prohibition of an interpretation contra legem, and it became an important aspect with regard to the question what 'as far as possible' requires. ${ }^{113}$ An example of this can be found in a judgment of the HR, delivered in 2014 . The difficulty in this case was that the Dutch rule made applicability of an exception contained in the Directive on credit agreements for consumers subject to a further condition that no purchase offers were directed to the public. ${ }^{114}$ The HR concluded that the national rule could not accommodate a consistent interpretation since this would contravene the unambiguous wording of the domestic

107 Albron par. 3.7.

108 HR 9 December 2011, ECLI:NL:HR:2011:BU7412, NJ 2013, 273, m.nt. Jac. Hijma.

109 Opinion of Advocate General Elmer in Case C-168/95 Arcaro, ECLI:EU:C:1996:107, par. 40; Opinion of Advocate General Jacobs in Centrosteel, par. 32.

110 Case note Verschuuren \& Jans, $M$ Q $R$ 2007, 45, par. 2.

11 See par. 16 of the court of appeal's judgment (included in the HR's judgment); Opinion of Advocate General Mok in Pink Floyd, par. 5.2.6.4. De Lange already recognises a relationship between Pink Floyd and the concept of contra legem in his case note, De Lange 1997, 120.

112 Administrative Jurisdiction Division 29 May 2001, ECLI:NL:RVS:2001:AB2282, JB 2001, 170, par. 2.5; Administrative Jurisdiction Division 7 December 2005, ECLI:NL:RVS:2005:AU7583, $A B$ 2006, 67, m.nt. R.J.G.M. Widdershoven, par. 7 .

113 Wissink 2014, 149.

114 See Directive 2008/48/EC of the European Parliament and of the Council of 23 April 2008 on credit agreements for consumers and repealing Council Directive 87/102/EEC [2008]

OJ L133/66. 
rule. ${ }^{115}$ The contra legem limitation was also addressed in a judgment of the Administrative Jurisdiction Division of 2014, the KWO judgment. The issue in this case was that the responsible administrative authority failed to coordinate the procedure for the water permit with that of the environmental permit. This was consistent with the Dutch Water Act, but contrary to Article 7, in connection with Article 2(9) of the IPPC Directive. A directive-consistent interpretation was dismissed, since this would require that the relevant provision of the Water Act did not only apply to discharges, but also to abstractions and infiltrations. Such an extensive interpretation was in no way compatible with the unambiguous wording of the national rule, which only mentioned the former. ${ }^{116}$

In keeping with the United Kingdom courts' approach towards the permissible degree of departure from the wording of the national rule, the prohibition of an interpretation contra legem is not a dominant feature in the case law. The argument of an interpretation contra legem was invoked by the defendant in the Dabas judgment, but it was dismissed without being given much consideration. ${ }^{117}$

\section{Conclusion}

These judgments show that the Dutch courts are more likely to look at the wording of the national rule, and sometimes allow this to override the presumption that the legislature intended to fulfil its EU law obligations in respect of implementing legislation (Van Asseldonk/Ter Schure, Fortis and KWO). It is interesting to see that in the Pink Floyd and Fortis judgments, reference is made to legal certainty; the permissible degree of distortion is then not exclusively approached from the perspective of the limits of the judicial function - which is dominant in the United Kingdom - but also from the perspective of intelligibility and consistency of the law (i.e. the perspective of the person seeking justice). The approach of the United Kingdom and Dutch courts towards the concept of contra legem ties in with the general picture. It is to be welcomed that the more recent judgments of the Dutch courts expressly refer to the prohibition of an interpretation contra legem, rather than providing in general terms that a consistent interpretation is not possible. The Albron judgment seems to take a more lenient approach towards the permissible degree of correction of the words enacted by the legislature. Further case law will have to be awaited before it can be determined whether Albron is an important precedent.

115 HR 13 June 2014, ECLI:NL:HR:2014:1385, Jurisprudentie Onderneming \& Recht 2014, 206, m.nt. J.W.A. Biemans, par. 3.5.4. I will subsequently refer to this judgment as 'Consumentenkrediet'.

${ }_{116}$ Administrative Jurisdiction Division 11 June 2014, ECLI:NL:RVS:2014:2120, AB 2014, 320, m.nt. S. Handgraaf, par. 2.7.

117 Dabas (Lord Brown), par. 79. 


\subsubsection{Arguments of Parliamentary Intention Contradicting the} Presumption of the Intention to Legislate in Compliance with EU Law

This refers to the situation where a more specific intention of the legislature is available for one or more provisions, which is inconsistent with the general presumption that the legislation was intended to comply with EU law. As far as the United Kingdom is concerned, the approach is closely related to what was written in the previous part of this subsection. Kavanagh explains that presumed intentions can only be rebutted by 'an unequivocal and clearly expressed enacted intention'. ${ }^{118}$ We therefore have to look at the letter of the law; intentions derived from, for example, Hansard are irrelevant. In the previous part it was explained that United Kingdom courts generally adopt a generous approach to consistent interpretation, so that the question arises as to what kind of statement is required from the legislature to override the aforementioned presumption. Craig addresses this question and predicts how the UKSC would decide a situation in which a United Kingdom statute expressly derogates from a provision of EU law, and unequivocally excludes application of the European Communities Act 1972:

'[i]f this occurred it might be argued that there would to that extent be no Act of Parliament by virtue of which EU law was recognized and available on the relevant topic in the UK. (...) The Supreme Court might decide that the UK derogating statute could be given effect pursuant to the traditional theory of parliamentary sovereignty (...). ${ }^{119}$

In his speech in the Macarthys judgment Lord Denning states:

'[th] us far I have assumed that our Parliament, whenever it passes legislation, intends to fulfil its obligations under the Treaty. If the time should come when our Parliament deliberately passes an Act - with the intention of repudiating the Treaty or any provision in it - or intentionally of acting inconsistently with it - and says so in express terms - then I should have thought that it would be the duty of our courts to follow the statute of our Parliament. ${ }^{, 120}$

In the Netherlands, consultation of legislative history is a well-established method of interpretation. This differs from the United Kingdom, which is in

118 Kavanagh 2006 , p. 186.

119 P.P. Craig, 'The European Union Act 2011: Locks, Limits and Legality' [2011] CML Rev. 1939. This prediction finds support in M. Gordon \& M. Dougan, 'The United Kingdom's European Union Act 2011: "who won the bloody war anyway?"' [2012] ELR 8.

120 Macarthys Ltd v. Smith [1979] ICR 785, 789. 
my opinion explained by the fact that in the latter Member State there is no single document which expounds on the intentions of 'the' legislature. ${ }^{121}$ However, the case law of the HR shows an interesting development, bringing its approach closer to that of the United Kingdom courts. The same approach was not found in the case law of the Administrative Jurisdiction Division; it is therefore uncertain whether the Administrative Jurisdiction Division will take a similar approach. The development in the HR's case law can be witnessed for the first time in the Wandelvierdaagse judgment. The HR first repeated the basic presumption of the legislature's intention to comply with EU law. Next, it introduced a '(...) modification of the general framework [the latter appears to refer to the framework of principles for the interpretation of national law; SWH] ${ }^{122}$ which entails that, if the formulation of a national rule allows for an interpretation that is in conformity with the directive, it will disregard an opposite interpretation derived from the parliamentary history. That would only be different if parliamentary history contains an explicit and unequivocal intention to disregard EU law obligations. Applying this new approach to the case at hand, the HR did not find any explicit intention to depart from EU law; the parliamentary history rather revealed an intention to comply with EU law in implementing the Sixth Directive. ${ }^{123}$ The same approach is applied in subsequent judgments of the HR. ${ }^{124}$

While courtesy towards the duty of consistent interpretation pervades the Wandelvierdaagse judgment, it also introduces two exceptions to this duty. The first exception refers to an explicit and unequivocal expression of the legislature's intention to depart from its EU law obligations in the parliamentary history. The exception is formulated slightly differently in subsequent judgments. In for example the Aci Adam e.a./Stichting De Thuiskopie judgment, the HR held that a divergent interpretation, derived from parliamentary history, had to be disregarded if the legislature intended to duly implement the directive and the national rule could accommodate a consistent interpretation. ${ }^{125}$ Widdershoven argues that the italicised part of the sentence corresponds to the exception formulated in the Wandelvierdaagse judgment. ${ }^{126}$ What is the legal basis of this

\footnotetext{
121 Kavanagh 2006, 182-3.

122 Wissink 2014, 147, 151.

123 Wandelvierdaagse, paras 3.4-3.5.

124 HR 6 June 2008, ECLI:NL:HR:2008:BD3139, AB 2008, 214, m.nt. R.J.G.M. Widdershoven (Joustra), par. 3.3.1; HR 21 September 2012, ECLI:NL:HR:2012:BW5879, AB 2012, 367, m.nt. R.J.G.M. Widdershoven (Aci Adam a.o./Stichting De Thuiskopie), par. 5.1.3; Albron, par. 3.6.8; Ryanair/PR Aviation, paras 3.5.1-3.5.2.

125 Aci Adam a.o./Stichting De Thuiskopie, par. 5.1.3. See also Albron, par. 3.6.8.

126 Case note Widdershoven for Aci Adam a.o./Stichting De Thuiskopie, par. 3. I agree, but on the face of it, the exception formulated in Aci Adam a.o./Stichting De Thuiskopie appears to be slightly broader.
} 
exception? Although application of this exception was rejected, the Wandelvierdaagse and Aci Adam e.a./Stichting De Thuiskopie judgments base the potential application of this limitation on the principle of legal certainty. In the Albron and Ryanair/PR Aviation judgments, which also apply the Wandelvierdaagse approach, this also seems to be the case. None of the cases refer to respect for the intentions of the legislature. ${ }^{127}$ The second exception contained in the Wandelvierdaagse judgment occurs where the formulation of the national rule does not allow for an interpretation that is in conformity with the directive (i.e. grammatical limitations which have already been discussed).

The Albron judgment, already mentioned in subsection 4.2.2, may have qualified the second exception in Wandelvierdaagse. ${ }^{128}$ In this judgment the presumption in favour of a consistent interpretation does not only trump more specific intentions supporting an alternative interpretation expressed in parliamentary history, but also where the latter is invoked in combination with the wording of the national rule. The HR concluded that the wording of a rule is not always decisive. Ryanair/PR Aviation is another application of the Wandelvierdaagse judgment. In this judgment an argument based on a more specific legislative intention, in combination with well-established case law, was also rejected by the HR. ${ }^{129}$

The Dutch HR's Wandelvierdaagse judgment, and the subsequent judgments, resemble the ECJ's Björnekulla judgment. Perhaps surprisingly, none of these judgments refer to the latter, but the HR does refer to the Wagner Miret judgment. It can be said that the Wagner Miret and Björnekulla judgments are premised on the same principle, and in a way the latter judgment made explicit what was already implicit in the Wagner Miret judgment. Yet, it should not be overlooked that if, for the sake of argument, it is accepted that the Björnekulla judgment entails an absolute 'obligation for national courts to disregard an interpretation based on legislative materials', it is questionable whether Wandelvierdaagse takes the same approach, for it still leaves open the possibility to reject a consistent interpretation if legislative history reveals clear signs that the legislature did not intend to duly implement the directive.

4.2.4 Coherence in the Application of Discretionary Elements of the Duty of Consistent Interpretation

It is not possible to establish prima facie cases of incoherence (or, conversely, coherence) with regard to the topics discussed in subsection

127 See in particular Wandelvierdaagse, par. 3.4, Aci Adam a.o./Stichting De Thuiskopie, par. 5.1.3.

128 cf. Wissink 2014, 153.

129 Ryanair/PR Aviation, paras 3.5.1-3.5.2. 
4.2. Establishing compliance with the ECJ's case law is not automatically sufficient; a more thorough analysis was required, premised on a Member State visà-vis Member State perspective. I would like to recall the key elements in terms of coherence, that were formulated in section 3: sticking together, representing a mutually supportive, symmetrical relationship, but at the same time maintaining scope for flexibility. Let it first be pointed out that three characteristics demonstrate that the domestic application of the duty of consistent interpretation sticks together and is in fact, at least to some extent, mutually supportive:

1. At least as far as implementing legislation is concerned, the presumed intention to legislate in compliance with EU law, has a strong impact on the United Kingdom's and Dutch approach to the duty of consistent interpretation and steers them in the same direction;

2. this natural coherence is embedded by the ECJ, predominantly through the Wagner Miret and Björnekulla judgments, but also the Pfeiffer judgment;

3. on a general level, both United Kingdom and Dutch courts require an unequivocal and express indication that, despite a presumption in favour of consistent interpretation, a consistent interpretation should be rejected.

At the same time there is not a uniform approach, and United Kingdom and Dutch courts use the flexibility, inherent in the design of the duty of consistent interpretation, to develop an approach that best suits the characteristics of their legal system. There are two striking differences in particular. Firstly, although it is clearly also an important feature in the Dutch case law, United Kingdom courts will in principle always approach consistent interpretation from the perspective of the relationship between courts and the legislature. In the United Kingdom, this permeates the application of all aspects of the duty of consistent interpretation (where it is established that the legislature's intention is to comply with EU law, courts will not hesitate to read words in or out of the legislation, sometimes adopting far-reaching interpretations. This can only be rebutted if the legislature clearly expressed an intention contrary to the presumption of compliance with EU law in respect of a fundamental feature of the legislation, and only those indications that can safely be attributed to the legislature are relevant). The approach of Dutch courts also leaves room for other considerations, such as legal certainty (in the sense of intelligibility and consistency of the law). Secondly, Dutch courts are more likely to include arguments based on parliamentary history; in the United Kingdom only enacted intentions are relevant. Although the Wandelvierdaagse, and subsequent judgments from the $\mathrm{HR}$ indicate that it will be less inclined to do so if this contradicts the general presumption that the legislature intended to comply with EU law, it has also recognised the possibility of rejecting a consistent interpretation when parliamentary history reveals an unequivocal intention to depart from EU law obligations. 
Are some of the differences sufficient to establish an incoherence? For sure, one can think of examples of individual cases in which a United Kingdom court adopts a decision that might not have been adopted by its Dutch counterpart (cf. for example the Dabas judgment and the Consumentenkrediet judgment). However, on account of the pluralistic features of the Member States, to which the United Kingdom and the Netherlands are no exception, it does not seem realistic to expect uniformity. I do not think that this is what coherence requires. Moreover, the approaches of the United Kingdom and Dutch courts remain within the boundaries of the ECJ's case law which keep the different approaches together.

\section{$5 \quad$ Concluding Remarks}

The hypothesis introduced at the beginning of the article was that, on account of its design, the duty of consistent interpretation can be applied coherently at the same time as respecting the pluralistic legal orders of the Member States. To check this hypothesis, I first examined the contents of the duty of consistent interpretation, and then went on to examine the concept of coherence. The core of this article was concerned with the relationship between these two, which was examined by analysing case law of the UKSC and the UKHL, and the Dutch HR and Administrative Jurisdiction Division.

This analysis showed that, although the United Kingdom and Dutch legal systems do not always share the same features, their approach towards discretionary aspects of the duty of consistent interpretation is remarkably coherent. Surprisingly, the most conspicuous instances of incoherence occurred in areas where the case law of the ECJ is relatively clear-cut. But is the coherent or incoherent application of the duty of consistent interpretation attributable to the design of the duty of consistent interpretation? Here the the Wagner Miret, Pfeiffer and Björnekulla judgments, but also the Marleasing judgment, which either stimulated or embedded coherent national approaches should be pointed out. But perhaps the design of the duty of consistent interpretation is the most important feature here. It allows for differentiation, and the need to weigh arguments in the specific context in which they are invoked. It also sets limits, and provides a common framework or language, that enables us to judge whether the divergent approaches can be said to hang together.

It was seen that the shared argument of a presumed legislative intention to comply with EU law was an important factor enabling coherence. On the basis of this article it is difficult to predict whether this only applies to implementing legislation, or other legislation as well. More generally, the question remains whether national courts take a similar approach when interpreting implementing legislation and other legislation. An answer to this question requires further analysis of case law in which the duty of consistent interpretation is applied to 
non-implementing legislation, as well as a systematic comparison with case law concerning implementing legislation. 